\title{
ANALISA SEBARAN SPASIAL IKAN CUCUT (Ordo Rajiformes) BERDASARKAN VARIASI KEDALAMAN DI PERAIRAN LAUT JAWA
}

\author{
Richan Fakhrurrizal, Sahala Hutabarat ${ }^{l}$, Agus Hartoko
}

Program Studi Manajemen Sumberdaya Perairan, Jurusan Perikanan

Fakultas Perikanan dan Ilmu Kelautan, Universitas Diponegoro

\begin{abstract}
ABSTRAK
Ikan cucut atau hiu termasuk dalam kategori ikan-ikan bertulang rawan (elasmobranchii). Cucut merupakan ikan demersal sehingga perlu diketahui kedalaman suatu perairan untuk mengetahui habitatnya. Kedalaman tersebut dapat diketahui dengan menggunakan penginderaan jauh. Penginderaan jauh merupakan suatu cara pengamatan objek tanpa menyentuh objek secara langsung. Tujuan penelitian adalah mengetahui perkembangan hasil tangkapan cucut, sebaran kedalaman di laut Jawa, dan hubungan antara sebaran kedalaman dengan hasil tangkapan cucut. Metode yang digunakan dalam penelitian ini adalah metode eksploratif. Pengambilan data menggunakan metode purposive sampling. Pertimbangan pengambilan data didasarkan pada hasil wawancara dengan nelayan setempat dan ketersediaan data produksi hasil tangkapan cucut yang dilengkapi titik koordinat lokasi penangkapan dari PPN Kejawanan pada tahun 2011 - 2012 adalah yang paling memadai, serta dilakukan pula analisa kedalaman yang berasal dari data batimetri laut Jawa. Analisis data yang digunakan adalah analisis korelasi antara kedalaman dengan hasil tangkapan cucut untuk mengetahui hubungan sebaran spasial ikan cucut dengan variasi kedalaman, didukung dengan studi pustaka tentang habitat ikan cucut. Hasil dari penelitian ini menunjukkan bahwa hasil tangkapan Cucut Junjunan (Rhynchobatus djiddensis) tertinggi didapatkan pada musim barat tahun 2011 dengan total hasil tangkapan $7440 \mathrm{~kg}$, sedangkan tangkapan Cucut Depo (Rhinobatos schegelii) tertinggi didapatkan pada musim timur tahun 2011 dengan total hasil tangkapan $7383 \mathrm{~kg}$. Variasi kedalaman di laut Jawa yang menunjukkan daerah penangkapan cucut pada musim timur berkisar antara 11 - $167 \mathrm{~m}$, dengan kedalaman rata-rata 80 m pada daerah penangkapan cucut Depo. Kedalaman pada musim barat berkisar antara $14-134$ $\mathrm{m}$, dengan kedalaman rata-rata $50 \mathrm{~m}$ pada daerah penangkapan cucut Junjunan. Secara umum nilai koefisien korelasi (r) setiap jenis cucut yang didapat pada musim timur maupun musim barat adalah $\leq 0,5$. Hal ini menunjukkan bahwa hubungannya rendah (tidak erat) yang berarti terdapat sedikit pengaruh kedalaman terhadap hasil tangkapan cucut di laut Jawa.
\end{abstract}

Kata Kunci: Ikan Cucut, Sebaran Spasial, Kedalaman, Batimetri, Laut Jawa.

\section{ABSTRACT}

Sharks or guitarfish are included in the category of cartilaginous fishes (elasmobranchii). Shark is demersal fish so that need to know the depth of the waters to find out the habitat of shark. The depth can be known by using remote sensing. Remote sensing is a method of observation objects without touching the object directly. The purpose of research is to know the development of shark catches, depth variation in the Java Sea, and the relationship between the depth variations with shark catches. The methods used in this research is explorative method. Data retrieval using a purposive sampling method. Consideration of data retrieval is based on the results of interviews with local fishermen and the availability of production data shark catches that equipped coordinates of the fishing ground from Kejawanan Archipelago in 2011 - 2012 is the most adequate, as well as the depth of analysis is also done from the Java Sea bathymetry data. The data used was analysis of correlation between depth with shark catches to determine the relationship of spatial distribution of shark catches with depth variations, supported by a study of the literature about habitat of shark. The results of this study indicate that catches of Junjunan shark (Rhynchobatus djiddensis) obtained the highest on the west monsoon in 2011 with total catches $7440 \mathrm{~kg}$, while the catches of Depo shark (Rhinobatos schegelii) obtained the highest on east monsoon in 2011 with total catches $7383 \mathrm{~kg}$. Depth variation in the Java Sea which indicates the fishing ground of shark on east monsoon ranged from $11-167$ $\mathrm{m}$, with depth average $80 \mathrm{~m}$ in fishing ground of Depo shark. Depth on west monsoon ranged between $14-$ $134 \mathrm{~m}$, with depth average $50 \mathrm{~m}$ in fishing ground of Junjunan Shark. In general the value of correlation coefficient ( $r$ ) each type of shark obtained in both east and west monsoon are $\leq 0,5$. This indicates low association (not tightly) which means there is little influence of depth toward sharks catches in the Java Sea.

Keywords: Shark, Spatial Distribution, Depth, Bathymetry, Java Sea.

*) Penulis Penanggung Jawab 


\section{Pendahuluan}

Indonesia tercatat sebagai salah satu negara yang memanfaatkan sumber daya ikan bertulang rawan (cucut dan pari) terbesar di dunia, dengan hasil tangkapan sebesar 103.245 ton pada tahun 2011 dan 105.230 ton pada tahun 2012. Ikan cucut dan pari yang tertangkap bisa sebagai hasil tangkapan sampingan maupun sebagai tangkapan utama (Direktorat Jenderal Perikanan Tangkap, 2012).

Ikan cucut termasuk dalam sub klas Elasmobranchii. Cucut termasuk hewan vivipar dan ovovivipar dengan fekunditas yang rendah, pertumbuhan dan kematangan gonadnya yang lambat, siklus reproduksi dan siklus hidupnya panjang. Jenis ikan cucut yang ada di dunia sekarang ini diperkirakan sekitar 375 - 500 jenis, dan dikelompokkan ke dalam delapan bangsa (order), 30 suku dan 100 marga. Pembagian kelompok jenis cucut tersebut umumnya didasarkan pada perbedaan bentuk morfologi yang mudah dikenali (FAO, 2002).

Pada umumnya cucut tersebar di berbagai jenis perairan dalam kondisi berkelompok maupun individual. Hal ini didukung oleh Stevens (1989) dalam Susanti (1997) memperjelas bahwa beberapa spesies cucut bergerak pada perairan dalam area yang cukup luas, sementara spesies yang lain bergerak dalam area yang lebih kecil atau area yang sama dari permukaan hingga perairan yang lebih dalam dan sebaliknya.

Cucut dapat ditemukan di seluruh perairan laut di dunia, mulai dari perairan tropis hingga ke daerah sub tropis, dan dari perairan pantai hingga ke lautan terbuka. Pada umumnya cucut hidup pada kedalaman 50 meter dari permukaan laut, tapi beberapa jenis cucut bahkan ada yang dapat hidup hingga kedalaman 800 meter (Pyers, 2000).

Menurut Bres (1993), faktor yang sangat berpengaruh terhadap penyebaran cucut adalah kedalaman perairan dan suhu, karena kedua faktor ini relatif tidak berubah. Kedalaman rata-rata dimana cucut berada, berkisar antara 70 - 1000 meter, walaupun demikian ada beberapa cucut yang hidup pada kedalaman lebih dari 1000 meter.

Teknologi penginderaan jauh (inderaja) merupakan teknologi yang digunakan untuk memperoleh informasi tentang obyek, daerah, atau gejala dengan jalan menganalisis menggunakan kaidah ilmiah terhadap data yang diperoleh dengan menggunakan alat tanpa kontak langsung terhadap obyek, daerah, atau gejala yang dikaji (Lillesand dan Kiefer, 1987).

Data yang digunakan untuk mengetahui kontur kedalaman yaitu data batimetri yang berasal dari satelit. Menurut Thurman (1997), satelit dapat digunakan untuk mengukur batimetri. Satelit radar memetakan topografi laut dalam dengan mendeteksi variasi halus di permukaan laut yang disebabkan oleh tarikan gravitasi bawah gunung, pegunungan, dan massa lainnya. Umumnya permukaan laut lebih tinggi di atas gunungan ridge dibandingkan dengan dataran abyssal dan trench.

Menurut Wyrtki (1961), kedalaman laut Jawa meningkat dari 20 meter pada pesisir Sumatera bagian selatan hingga lebih dari 60 meter pada bagian timurnya. Kondisi oseanografi di laut Jawa dipengaruhi oleh adanya 2 angin muson, yaitu angin muson timur dan angin muson barat yang bertiup secara berkala sepanjang tahun di atas perairan laut Jawa.

Tujuan dari penelitian ini adalah untuk mengetahui perkembangan hasil tangkapan dan mengetahui musim puncak penangkapan ikan cucut, berdasarkan data hasil tangkapan ikan Cucut yang di daratkan di PPN Kejawanan pada tahun 2011 - 2012, kemudian untuk mengetahui sebaran kedalaman di daerah penangkapan ikan Cucut di perairan laut Jawa, serta untuk mengetahui keeratan hubungan (korelasi) antara sebaran kedalaman dengan rata-rata jumlah tangkapan di laut Jawa.

\section{Materi dan Metode Penelitian}

\section{A. Materi Penelitian}

Materi yang digunakan dalam penelitian ini adalah data batimetri laut Jawa, data produksi ikan Cucut bulanan dan data wilayah penangkapan ikan Cucut berupa titik koordinat penangkapan dari Pelabuhan Perikanan Nusantara Kejawanan, Cirebon selama 2 tahun yaitu tahun 2011-2012 serta kuisioner untuk melakukan proses wawancara terhadap nelayan kapal penangkap ikan cucut yang meliputi titik koordinat penangkapan ikan Cucut, hasil tangkapan per titik koordinat, deskripsi kapal dan alat tangkap gillnet (liong bun), serta faktor-faktor yang mempengaruhi hasil tangkapan ikan Cucut. Alat yang digunakan adalah perangkat keras yaitu laptop dengan prosesor Intel Core i5 untuk melakukan seluruh proses pengolahan data dan laporan penelitian, perangkat lunak ER-Mapper 7.0 untuk melakukan proses gridding (geo statistik), overlay dan layout peta persebaran kedalaman.

\section{B. Metode Penelitian}

Metode penelitian yang digunakan yaitu metode eksploratif. Menurut Hamidi (2007), penelitian eksploratif adalah penelitian yang bertujuan untuk mencari tahu suatu kejadian sosial tertentu atau hubungan antara dua atau lebih variabel. Tujuan dari penelitian eksploratif antara lain:

1. Memuaskan rasa atau hasrat ingin tahu agar memperoleh pemahaman lebih jelas tentang peristiwa sosial yang terjadi;

2. Memperoleh tingkat kelayakan melakukan penelitian yang lebih teliti, careful study;

3. Mengembangkan metode-metode yang hendak digunakan dalam penelitian yang lebih teliti. 
Terdapat pula metode lainnya seperti metode purposive sampling, metode studi pustaka dan metode dokumentasi. Metode purposive sampling digunakan peneliti jika memiliki pertimbangan-pertimbangan tertentu di dalam pengambilan sampel atau penentuan sampel untuk tujuan tertentu. Metode pustaka dilakukan dalam mempelajari teori-teori yang mendukung penelitian, sehingga diharapkan dengan landasan teori yang kuat akan diperoleh pemahaman yang baik. Metode tersebut dapat digunakan untuk mencari data sekunder sebagai data primer yang didapatkan dari lapangan. Metode dokumentasi ini bersifat sekunder tergantung oleh peneliti, dengan mendokumentaikan beberapa proses atau keadaan saat berlangsungnya kegiatan penelitian (Nasir, 1983).

\section{Metode Pengambilan Data}

Pengambilan data dilakukan dengan metode purposive sampling. Pertimbangan pengambilan data ini didasarkan pada hasil wawancara dengan nelayan setempat dan ketersediaan data produksi hasil tangkapan cucut yang dilengkapi titik koordinat lokasi penangkapan dari PPN Kejawanan, Cirebon pada tahun 2011 2012 adalah yang paling memadai, serta dilakukan pula pengolahan kontur kedalaman yang berasal dari data batimetri laut Jawa. Data tangkapan ikan cucut yang digunakan meliputi data koordinat lokasi penangkapan ikan cucut dan jumlah ikan cucut yang tertangkap di setiap koordinat penangkapan, sedangkan pengolahan data batimetri dilakukan di Jurusan Perikanan, Fakultas Perikanan dan Ilmu Kelautan, Universitas Diponegoro.

\section{Pengolahan Data}

Pengolahan data citra ini bertujuan untuk mempertajam data digital menjadi suatu tampilan yang dapat memberikan informasi. Hasil-hasil pengolahan citra dalam bentuk peta digital tidak mudah diinterpretasikan secara langsung sehingga diperlukan teknologi SIG untuk menggambarkannya dalam bentuk peta tematik sehingga kita dapat melakukan analisis sebaran kedalaman dan lokasi penangkapan ikan Cucut. Data yang digunakan adalah data batimetri dan data hasil tangkapan Cucut beserta titik koordinat lokasi penangkapannya. Tahapan prosedur pengolahan data yang dilakukan yaitu sebagai berikut:

1. Plotting titik koordinat

Plotting titik koordinat bertujuan untuk mengetahui lokasi penangkapan serta mengubah format titik koordinat yang didapat dari GPS (Derajat, Menit, Detik) menjadi derajat desimal, karena pada pengolahan selanjutnya di software ER-Mapper 7.0, harus menggunakan titik koordinat dengan format derajat desimal. Proses plotting ini menggunakan software Google Earth.

2. Gridding

Gridding merupakan proses transformasi data titik koordinat lapangan dan variabel pendukung menjadi layer spasial (Hartoko dan Helmi, 2004). Gridding bertujuan untuk mengetahui sebaran titik koordinat beserta nilai hasil tangkapannya. Data yang digunakan pada proses gridding ini adalah titik koordinat (derajat desimal) dengan hasil tangkapan Cucut. Proses gridding hingga proses pembuatan layout menggunakan software ER-Mapper 7.0, kemudian hasil dari proses gridding ini selanjutnya akan di-overlay dengan data batimetri yang telah di-cropping.

3. Cropping (Pemotongan citra)

Pemotongan citra bertujuan untuk menyesuaikan ukuran citra dan membatasi wilayah pengamatan dengan objek yang akan dikaji. Data batimetri dipotong sesuai dengan lokasi penelitian yaitu wilayah perairan laut Jawa.

4. Counturing

Counturing merupakan proses untuk menampilkan kontur suatu permukaan yang dibedakan dalam bentuk garis. Tujuan dari counturing ini yaitu untuk mengetahui kedalaman yang terdapat laut Jawa, khususnya kedalaman pada titik lokasi penangkapan Cucut.

5. Overlay

Overlay dilakukan dengan membandingkan kedua data yang ada dan telah diolah. Tujuan dilakukan overlay untuk melihat apakah ada suatu perubahan atau perbedaaan antara data satu dengan data yang lainnya. Data yang di-overlay pada penelitian ini adalah data hasil gridding dan data batimetri yang telah dicropping.

6. Pembuatan layout

Pembuatan layout peta hasil pengolahan data yang dilakukan pada software ER Mapper 7 bertujuan untuk memperjelas dan memberi tampilan peta beserta data-data yang tercakup di dalamnya. Hasil yang didapat kemudian ditampilkan dalam bentuk peta sebarannya.

\section{E. Analisis Korelasi}

Analisis untuk menilai hubungan antara nilai kedalaman pada lokasi penangkapan ikan Cucut dengan hasil produksinya yaitu digunakan analisis regresi dan korelasi sederhana. Analisis ini menggunakan data produksi penangkapan ikan Cucut, dan data nilai kedalaman. Pengolahan data untuk analisis ini menggunakan software Past, SPSS 16 dan Microsoft Excel 2003, maka akan didapatkan nilai koefisien korelasi ( $r$ ) dan nilai koefisien determinasi $\left(\mathrm{R}^{2}\right)$. Menurut Hadi (2004), koefisien korelasi selalu bergerak diantara $-1 \geq \mathrm{r} \leq 1$. Koefisien korelasi antara 0 sampai +1 menunjukkan korelasi yang positif sedangkan dari -1 sampai 0 menunjukkan korelasi yang negatif. 
Tabel 1. Klasifikasi Nilai Koefisien Korelasi

\begin{tabular}{cc}
\hline Koefisien Korelasi (r) & Interpretasi \\
\hline $0,8-1$ & Tinggi \\
$0,6-0,8$ & Cukup tinggi \\
$0,4-0,6$ & Agak rendah \\
$0,2-0,4$ & Rendah \\
$0,0-0,2$ & Sangat rendah (Tak berkorelasi) \\
\hline
\end{tabular}

Sumber : Hadi (2004)

Analisis regresi yang dilakukan yaitu regresi tunggal (single regression) berdasarkan spesies Cucut dan regresi tunggal (single regression) berdasarkan musim penangkapan.

1. Regresi tunggal (single regression) berdasarkan spesies Cucut

Regresi tunggal ini dilakukan dengan menghubungkan nilai kedalaman dan hasil tangkapan Cucut per spesies. Analisis regresi ini dilakukan untuk mengetahui apakah hasil tangkapan Cucut per spesies dipengaruhi oleh kedalaman atau tidak. Regresi ini menggunakan persamaan polinomial yaitu:

dimana:

$$
\mathbf{Y}=\mathbf{a}+\mathbf{b x}+\mathbf{c \mathbf { x } ^ { 2 }}
$$

$\mathrm{Y} \quad=$ variabel terikat (hasil tangkapan Cucut per spesies)

$\mathrm{X} \quad=$ variabel bebas (kedalaman setiap titik koordinat lokasi penangkapan)

$\mathrm{a}=$ constant

$\mathrm{b}, \mathrm{c} \quad=$ koefisien

2. Regresi tunggal (single regression) berdasarkan tahun musim penangkapan

Regresi tunggal ini dilakukan dengan menghubungkan nilai kedalaman dan hasil tangkapan Cucut total pada setiap musim penangkapan. Analisis regresi ini dilakukan untuk mengetahui apakah hasil tangkapan Cucut secara keseluruhan dipengaruhi oleh kedalaman pada musim barat atau timur. Regresi ini menggunakan persamaan polinomial yaitu:

dimana:

$$
\mathbf{Y}=\mathbf{a}+\mathbf{b x}+\mathbf{c x ^ { 2 }}
$$

$$
\begin{array}{ll}
\mathrm{Y} & =\text { variabel terikat (hasil tangkapan Cucut total) } \\
\mathrm{X} & =\text { variabel bebas (kedalaman setiap tahun musim penangkapan) } \\
\mathrm{a} & =\text { constant } \\
\mathrm{b}, \mathrm{c} & =\text { koefisien }
\end{array}
$$

\section{Hasil dan Pembahasan}

A. Hasil

\section{Kondisi Umum Lokasi Penelitian}

Pelabuhan Perikanan Nusantara (PPN) Kejawanan Cirebon merupakan satu pelabuhan perikanan dan pangkalan pendaratan ikan yang ada di Indonesia. PPN Kejawanan yang mempunyai tugas melaksanakan fasilitas produksi dan pemasaran hasil perikanan tangkap di wilayahnya dituntut untuk dapat memenuhi permintaan masyarakat akan kebutuhan ikan. Kemampuan untuk memenuhi permintaan tersebut harus didukung dengan kemampuan nelayan untuk dapat menghasilkan produksi ikan yang memadai. Pelabuhan Perikanan Nusantara Kejawanan terletak di Kelurahan Pegambiran Kecamatan Lemahwungkuk Kota Cirebon tepatnya pada posisi $06^{\circ} 44^{\prime} 14^{\prime \prime} \mathrm{LS} / 108^{\circ} 34^{\prime}$ '54" BT, dengan posisi pantai menghadap timur laut.Daerah penangkapan kapal-kapal ikan yang mendaratkan ikan hasil tangkapannya di PPN Kejawanan adalah laut Cina Selatan, selat Karimata, laut Jawa, selat Makassar dan laut Flores. Kapal yang mendaratkan ikan hasil tangkapannya di PPN Kejawanan adalah kapal dengan alat tangkap "liongbun" (bottom gillnet) yang merupakan alat tangkap untuk ikan demersal, serta jala cumi-cumi (bouke ami) yang khusus menangkap cumi-cumi. Dengan demikian, potensi sumberdaya ikan untuk PPN Kejawanan adalah ikan demersal dan cumi-cumi yang ada di ketiga Wilayah Pengelolaan Perikanan (WPP) tersebut.

\section{Perkembangan Hasil Tangkapan Cucut}

Cucut yang ditangkap di perairan laut Jawa terdiri dari dua jenis yaitu Cucut Depo (Rhinobatos schlegelii), dan Cucut Junjunan (Rhynchobatus djiddensis). Perkembangan hasil tangkapan setiap jenis Cucut dapat dilihat pada Gambar 1 berikut: 


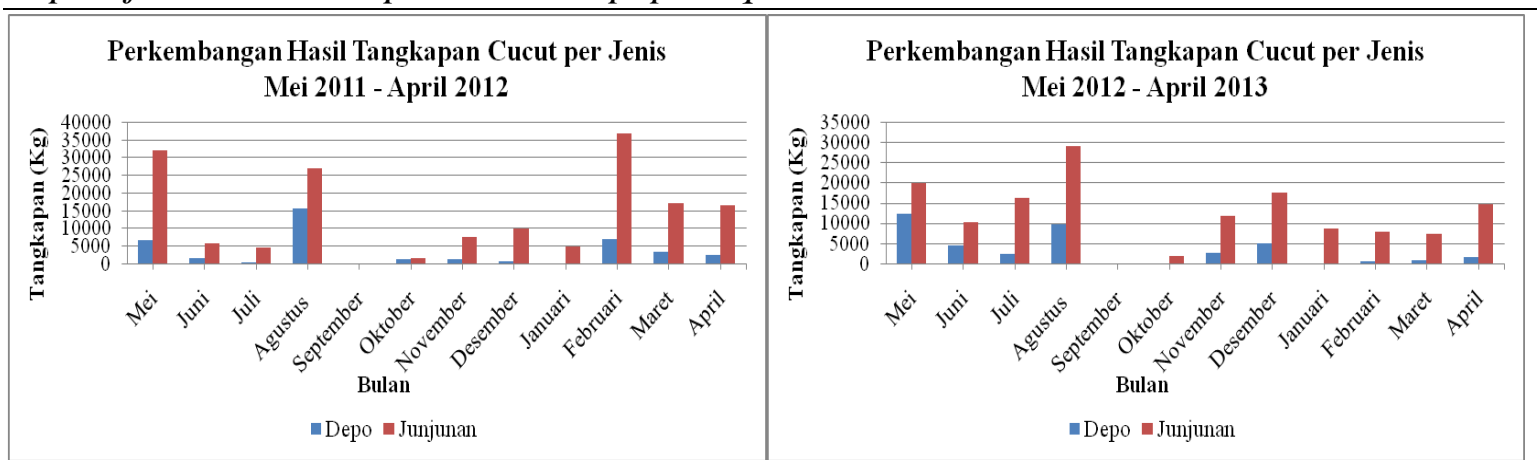

Gambar 1. Perkembangan Tangkapan Cucut per Jenis Tahun 2011 dan Tahun 2012

Perkembangan Trip Penangkapan Cucut

Trip penangkapan merupakan faktor eksternal yang dapat mempengaruhi hasil tangkapan Cucut di suatu perairan. Perkembangan trip penangkapan Cucut pada Gambar 2 berikut:

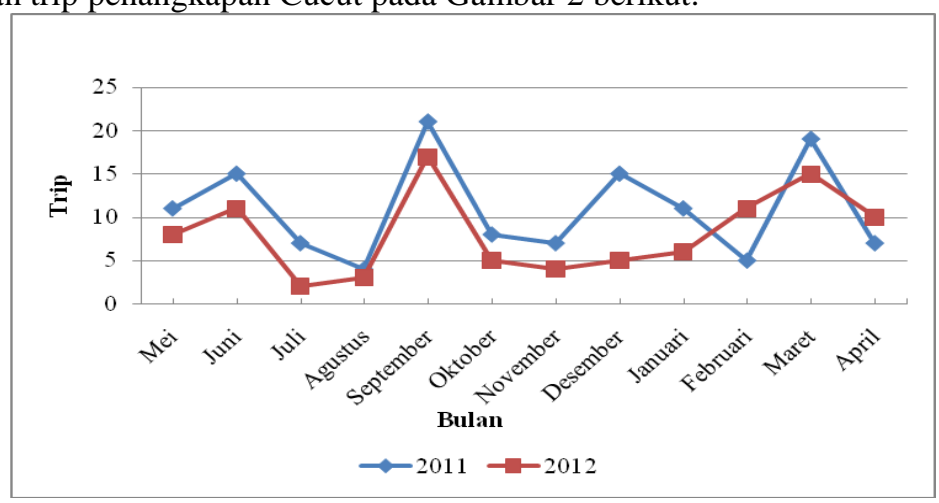

Gambar 2. Perkembangan Trip Penangkapan Cucut

Sebaran Tangkapan Cucut dan Variasi Kedalaman di Laut Jawa

Berdasarkan dari hasil pengolahan data batimetri serta data hasil tangkapan Cucut di Laut Jawa pada setiap musim, didapatkan kedalaman pada setiap musimnya yang tersaji pada Tabel 2 berikut:

Tabel 2. Kedalaman pada Setiap Musim Penangkapan

\begin{tabular}{|c|c|c|}
\hline Musim & $\mathbf{2 0 1 1}$ & $\mathbf{2 0 1 2}$ \\
\hline Timur & $20-167 \mathrm{~m}$ & $11-149 \mathrm{~m}$ \\
\hline Barat & $14-134 \mathrm{~m}$ & $14-120 \mathrm{~m}$ \\
\hline
\end{tabular}

Sumber: (Hasil Penelitian, 2013)

Sebaran Spasial Tangkapan Ikan Cucut dan Variasi Kontur Kedalaman di Laut Jawa pada setiap musimnya tersaji pada Gambar 3, Gambar 4, Gambar 5, dan Gambar 6 berikut:

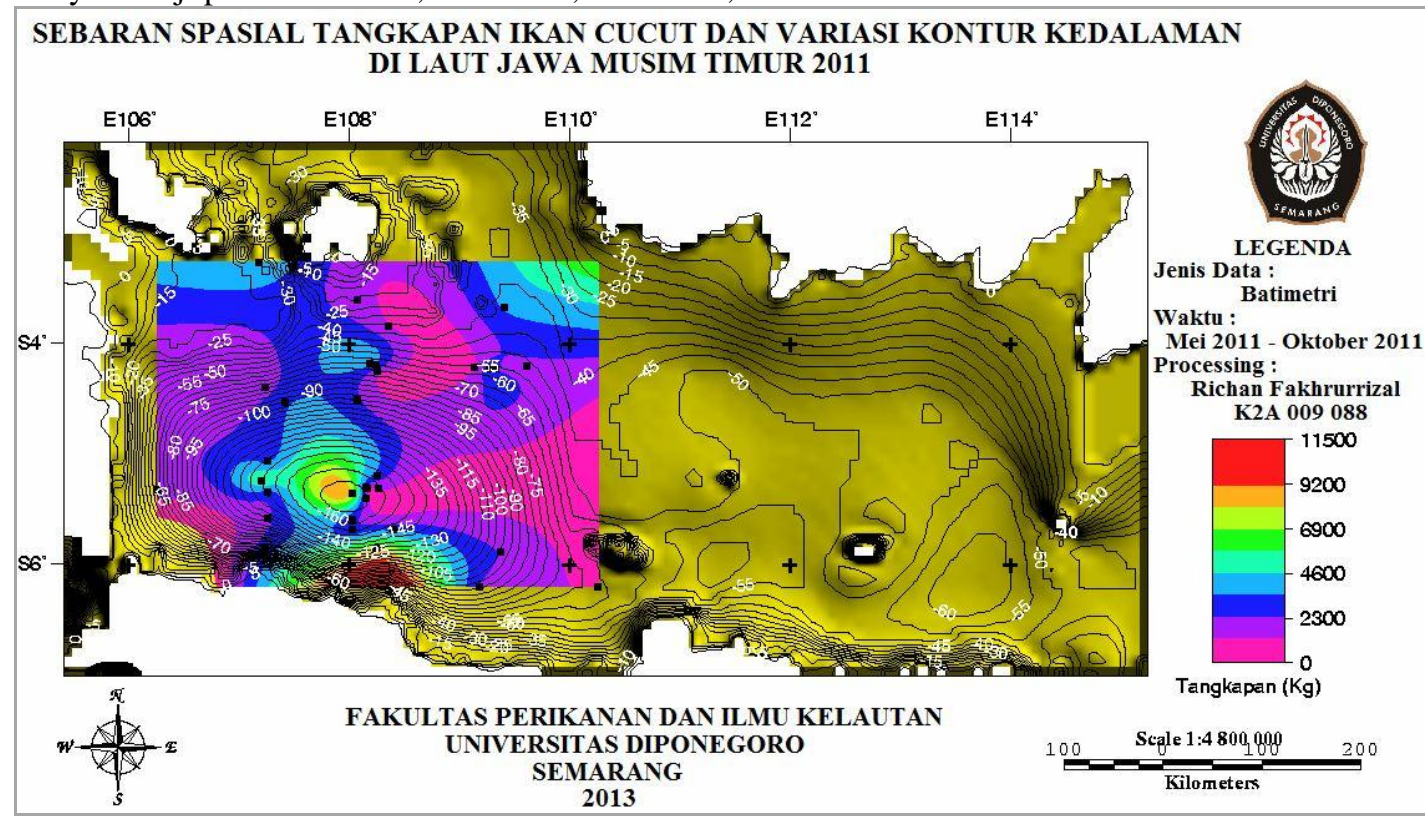

Gambar 3. Peta Sebaran Spasial Tangkapan Cucut dan Variasi Kontur Kedalaman Musim Timur Tahun 2011 
SEBARAN SPASIAL TANGKAPAN IKAN CUCUT DAN VARIASI KONTUR KEDALAMAN
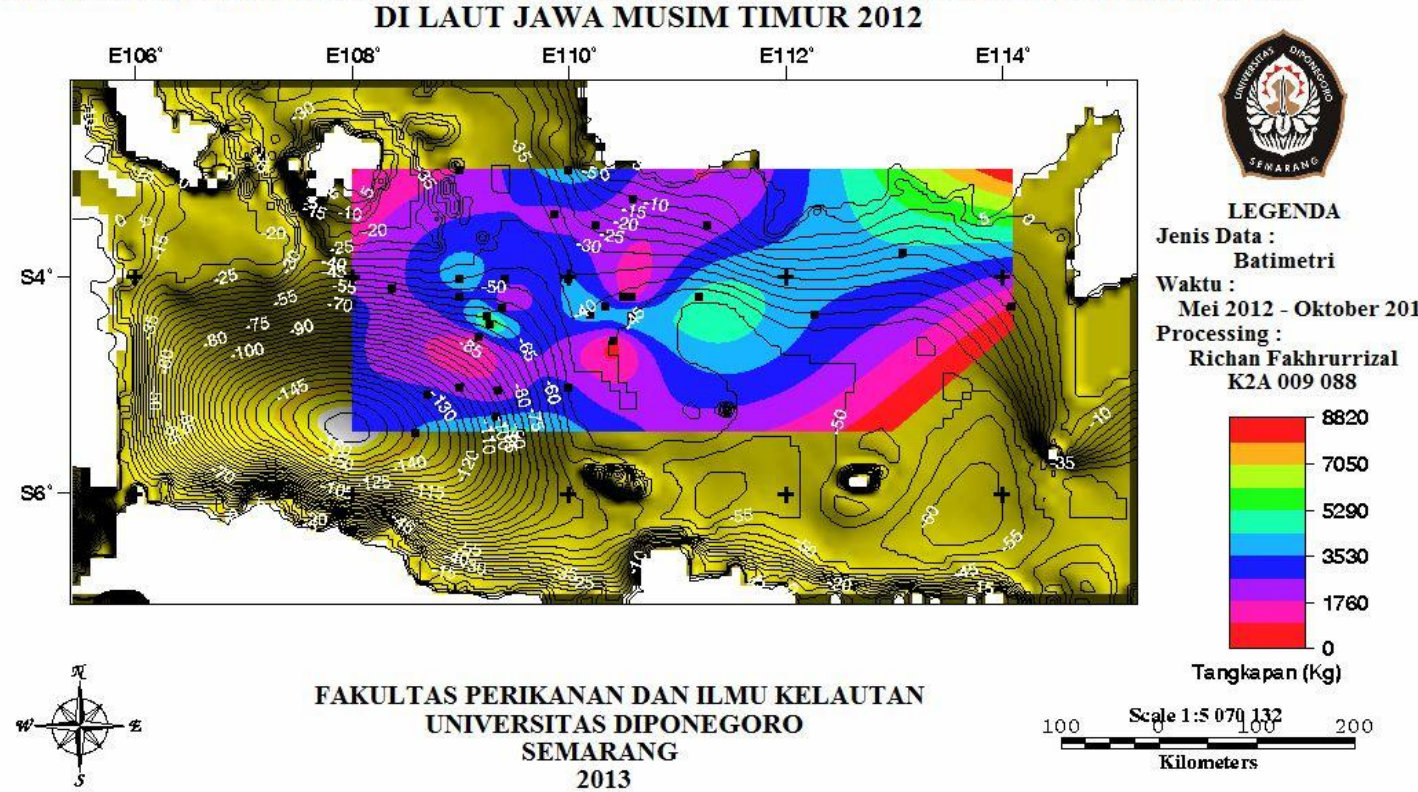

FAKULTAS PERIKANAN DAN ILMU KELAUTAN UNIVERSITAS DIPONEGORO SEMARANG 2013

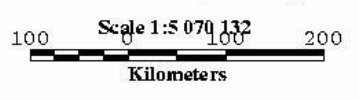

Gambar 4. Peta Sebaran Spasial Tangkapan Cucut dan Variasi Kontur Kedalaman Musim Timur Tahun 2012

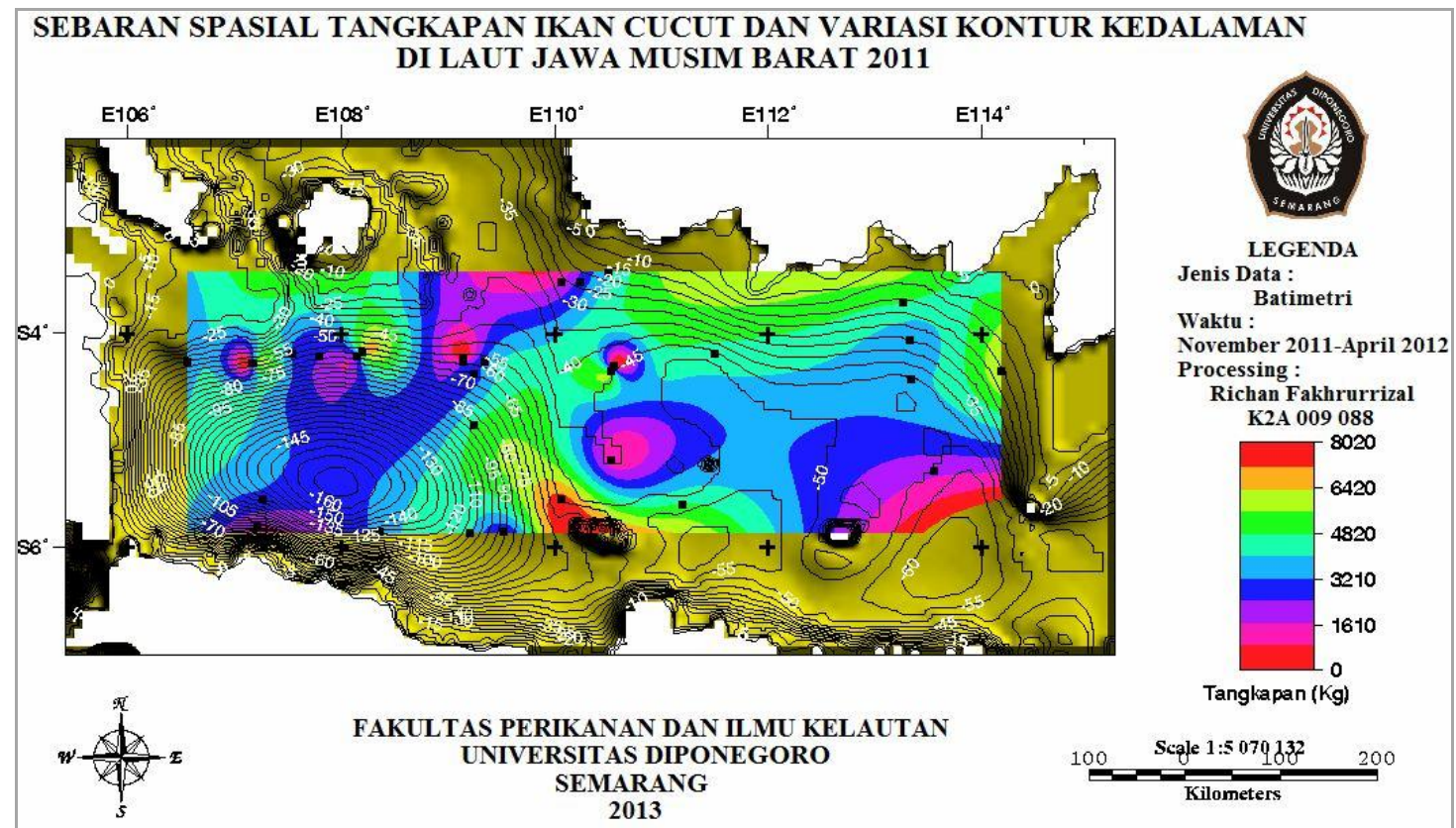

Gambar 5. Peta Sebaran Spasial Tangkapan Cucut dan Variasi Kontur Kedalaman Musim Barat Tahun 2011 


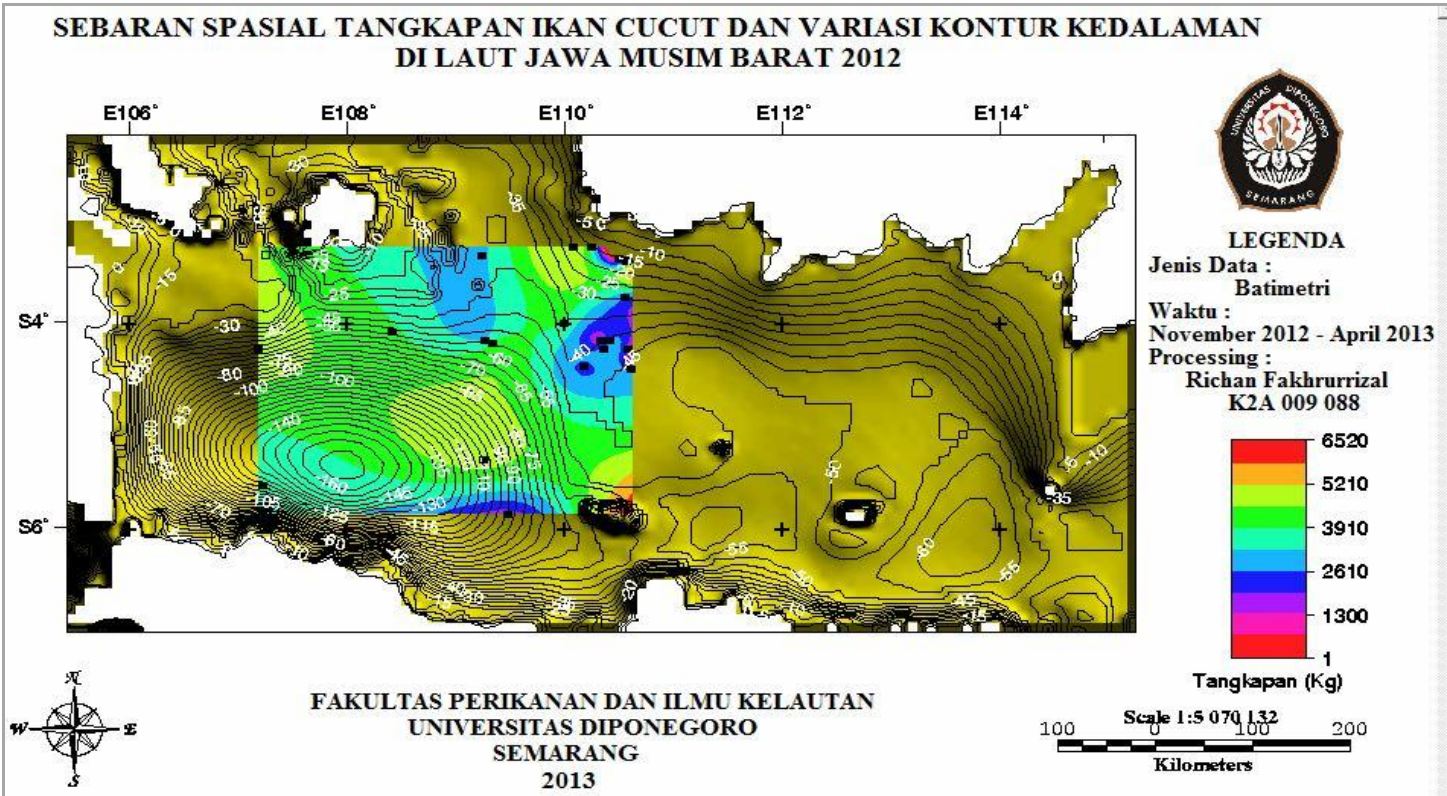

Gambar 6. Peta Sebaran Spasial Tangkapan Cucut dan Variasi Kontur Kedalaman Musim Barat Tahun 2012

\section{Analisis Korelasi antara Kedalaman dengan Hasil Tangkapan Cucut}

Analisis korelasi antara kedalaman dengan hasil tangkapan Cucut dilakukan dengan menggunakan regresi. Hasil analisis korelasi adalah sebagai berikut:

Regresi Tunggal (Single Regression) per Spesies

Analisis regresi tunggal per spesies Cucut artinya melakukan analisis regresi antara kedalaman dengan hasil tangkapan per spesies Cucut. Berikut adalah hasil analisis regresi antara kedalaman dengan hasil tangkapan Cucut per jenis pada musim timur tahun 2011 dan 2012.

Tabel 3. Hasil Analisis Korelasi Regresi Tunggal (Single Regression) pada Hasil Tangkapan Cucut per Spesies dan Kedalaman Musim Timur Tahun 2011

\begin{tabular}{cccccc}
\hline Tangkapan Cucut & Persamaan Polinomial & $\mathbf{r}$ & $\mathbf{R}^{2}$ & Sig & $\begin{array}{c}\text { Kedalaman } \\
\text { rata-rata (m) }\end{array}$ \\
\hline $\begin{array}{c}\text { Depo (Rhinobatos } \\
\text { schlegelii) }\end{array}$ & $\mathrm{Y}=705.8-9.799 \mathrm{x}-0.092 \mathrm{x}^{2}$ & 0.329 & 0.108 & 0.240 & $104 \mathrm{~m}$ \\
$\begin{array}{c}\text { Junjunan (Rhynchobatus } \\
\text { djiddensis) }\end{array}$ & $\mathrm{Y}=1503+17.62 \mathrm{x}-0.098 \mathrm{x}^{2}$ & 0.184 & 0.034 & 0.590 & $100 \mathrm{~m}$ \\
\hline
\end{tabular}

Sumber: (Hasil Penelitian, 2013)

Tabel 4. Hasil Analisis Korelasi Regresi Tunggal (Single Regression) pada Hasil Tangkapan Cucut per Spesies dan Kedalaman Musim Timur Tahun 2012

\begin{tabular}{cccccc}
\hline Tangkapan Cucut & Persamaan Polinomial & $\mathbf{r}$ & $\mathbf{R}^{2}$ & Sig & $\begin{array}{c}\text { Kedalaman } \\
\text { rata-rata }(\mathbf{m})\end{array}$ \\
\hline $\begin{array}{c}\text { Depo (Rhinobatos } \\
\text { schlegelii) }\end{array}$ & $\mathrm{Y}=190.7+24.49 \mathrm{x}-0.133 \mathrm{x}^{2}$ & 0.308 & 0.095 & 0.286 & $56 \mathrm{~m}$ \\
$\begin{array}{c}\text { Junjunan (Rhynchobatus } \\
\text { djiddensis) }\end{array}$ & $\mathrm{Y}=2032+6.814 \mathrm{x}-0.041 \mathrm{x}^{2}$ & 0.063 & 0.004 & 0.940 & $55 \mathrm{~m}$ \\
\hline
\end{tabular}

Sumber: (Hasil Penelitian, 2013)
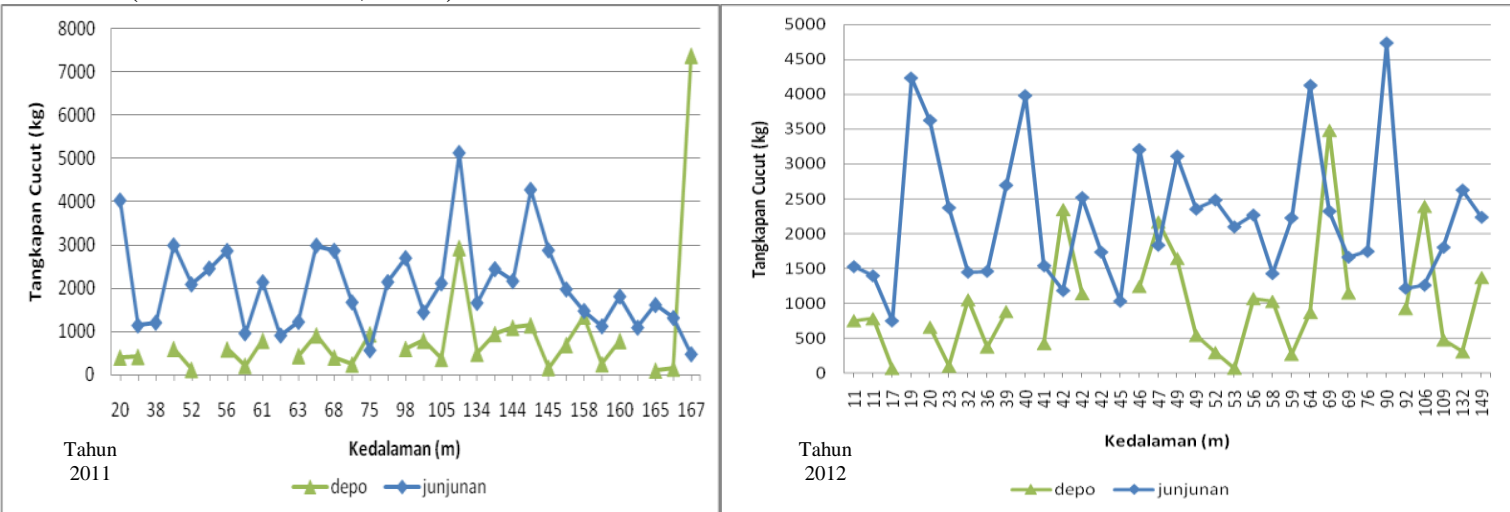

Gambar 7. Grafik Tangkapan Ikan Cucut per Spesies berdasarkan Kedalaman pada Musim Timur 
Berikut adalah hasil analisis regresi antara kedalaman dengan hasil tangkapan Cucut per jenis pada musim barat tahun 2011 dan 2012.

Tabel 5. Hasil Analisis Korelasi Regresi Tunggal (Single Regression) pada Hasil Tangkapan Cucut per Spesies dan Kedalaman Musim Barat Tahun 2011

\begin{tabular}{cccccc}
\hline Tangkapan & Persamaan Polinomial & $\mathbf{r}$ & $\mathbf{R}^{2}$ & Sig & $\begin{array}{c}\text { Kedalaman } \\
\text { rata-rata (m) }\end{array}$ \\
\hline $\begin{array}{c}\text { Depo (Rhinobatos } \\
\text { schlegelii) }\end{array}$ & $\mathrm{Y}=729.5+1.592 \mathrm{x}-0.047 \mathrm{x}^{2}$ & 0.224 & 0.050 & 0.596 & $62 \mathrm{~m}$ \\
$\begin{array}{c}\text { Junjunan (Rhynchobatus } \\
\text { djiddensis) }\end{array}$ & $\mathrm{Y}=4137-34.96 \mathrm{x}+0.2184 \mathrm{x}^{2}$ & 0.184 & 0.034 & 0.629 & $58 \mathrm{~m}$ \\
\hline
\end{tabular}

Sumber: (Hasil Penelitian, 2013)

Tabel 6. Hasil Analisis Korelasi Regresi Tunggal (Single Regression) pada Hasil Tangkapan Cucut per Spesies dan Kedalaman Musim Barat Tahun 2012

\begin{tabular}{cccccc}
\hline Tangkapan & Persamaan Polinomial & $\mathbf{r}$ & $\mathbf{R}^{2}$ & Sig & $\begin{array}{c}\text { Kedalaman } \\
\text { rata-rata (m) }\end{array}$ \\
\hline $\begin{array}{c}\text { Depo (Rhinobatos } \\
\text { schlegelii) }\end{array}$ & $\mathrm{Y}=865.3-6.917 \mathrm{x}+0.014 \mathrm{x}^{2}$ & 0.266 & 0.071 & 0.595 & $45 \mathrm{~m}$ \\
$\begin{array}{c}\text { Junjunan (Rhynchobatus } \\
\text { djiddensis) }\end{array}$ & $\mathrm{Y}=2113+15.35 \mathrm{x}-0.029 \mathrm{x}^{2}$ & 0.321 & 0.103 & 0.375 & $49 \mathrm{~m}$ \\
\hline
\end{tabular}

Sumber: (Hasil Penelitian, 2013)
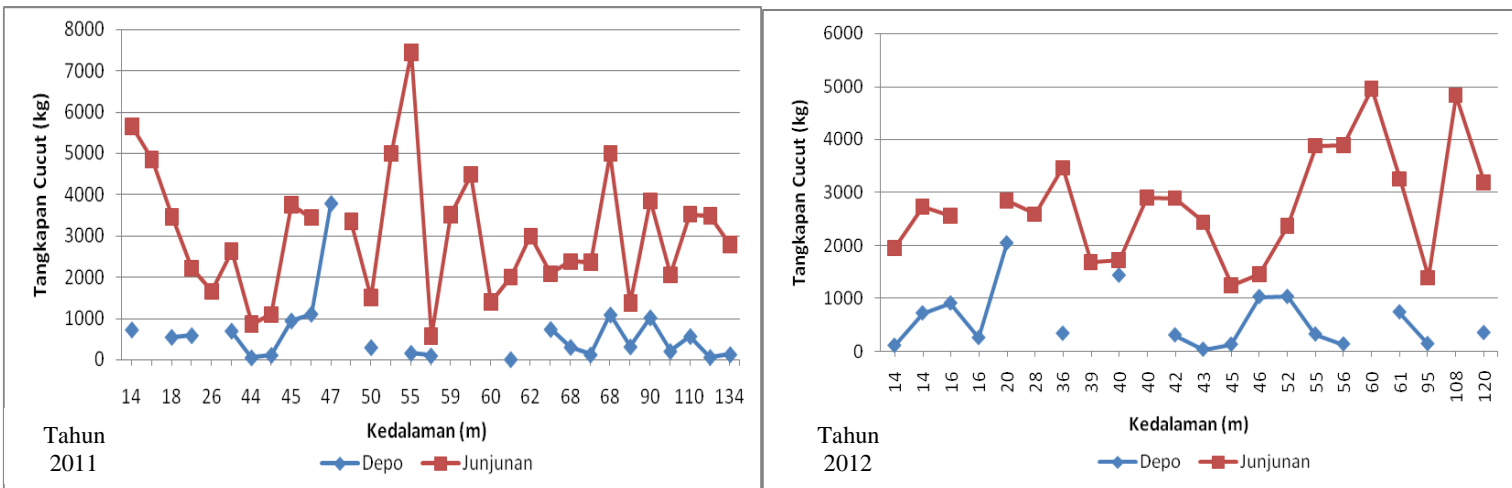

Gambar 8. Grafik Tangkapan Ikan Cucut per Spesies berdasarkan Kedalaman pada Musim Barat

\section{B. Pembahasan}

\section{Perkembangan Hasil Tangkapan Cucut dengan Trip Penangkapan}

Penangkapan ikan Cucut di Pelabuhan Perikanan Nusantara Kejawanan menggunakan kapal liongbun berukuran $28-48$ GT dengan alat tangkap bottom gillnet. Ikan Cucut yang diteliti pada penelitian ini terdiri dua jenis, yaitu Cucut Depo (Rhinobatos schlegelii) dan Cucut Junjunan (Rhynchobatus djiddensis). Berdasarkan Gambar 6 dan Gambar 7 di atas dapat diketahui bahwa produksi ikan secara umum di PPN Kejawanan mengalami fluktuasi setiap tahunnya, dengan produksi tertinggi dicapai pada tahun 2011 yaitu sebesar $203.351 \mathrm{~kg}$ dan mengalami penurunan produksi pada tahun 2012 dengan jumlah produksi sebesar $188.627 \mathrm{~kg}$.

Ikan cucut yang tertangkap di perairan laut Jawa dan di daratkan di PPN Kejawanan Cirebon terdiri dari dua jenis cucut yang dikenal dengan nama lokal di daerah Cirebon yaitu Cucut Depo (Rhinobatos schlegelii), dan Cucut Junjunan (Rhynchobatus djiddensis). Penyebaran Cucut di laut Jawa belum banyak diketahui karena wilayah perairannya dipengaruhi oleh musim, serta pergerakan arus yang dapat mempengaruhi keberadaan cucut tersebut. Menurut Hutabarat dan Evans (1985), secara umum gerakan arus permukaan laut terutama disebabkan oleh adanya angin yang bertiup di atasnya. Salah satu faktor yang mempengaruhi arus permukaan laut yaitu arus musiman atau arus yang disebabkan oleh musim.

Berdasarkan grafik perkembangan penangkapan Cucut, menunjukkan bahwa hasil tangkapan Cucut secara umum lebih tinggi pada musim barat 2011 (Februari) dengan total hasil tangkapan cucut Junjunan $36849 \mathrm{~kg}$, karena terjadi peningkatan trip penangkapan pada bulan Desember sehingga hasil tangkapan pada bulan Februari terjadi peningkatan pula, sebab dalam penangkapan cucut diperlukan waktu kurang lebih 3 bulan. Pada musim timur 2012 (Agustus) didapatkan total hasil tangkapan cucut Junjunan $28863 \mathrm{~kg}$, karena trip penangkapan pada bulan Juni jumlahnya banyak sehingga hasil tangkapan pada bulan Agustus juga meningkat. Hasil tangkapan Cucut Junjunan lebih tinggi dibanding Cucut Depo pada setiap bulan, karena tangkapan utama kapal ini adalah cucut Junjunan. Pada setiap tahun di bulan September tidak mendapatkan hasil tangkapan Cucut sama sekali, karena pada bulan September banyak kapal yang baru berangkat melaut. 
Sedangkan berdasarkan grafik trip penangkapan, dapat dilihat bahwa trip penangkapan lebih tinggi pada tahun 2011 daripada tahun 2012, hal tersebut dikarenakan terjadi pengurangan jumlah trip pada tahun 2012. Jumlah trip penangkapan ini dipengaruhi oleh masalah teknis operasional kapal seperti perbaikan kapal yang rusak dapat menghabiskan waktu yang lama serta kondisi cuaca yang tidak menentu seperti pada saat musim pancaroba atau musim peralihan.

Trip penangkapan selalu berhubungan dengan keberangkatan kapal tangkap/ armada serta alat tangkap yang digunakan. Kapal yang digunakan oleh nelayan jaring liongbun (bottom gillnet) di PPN Kejawanan Cirebon umumnya terbuat dari kayu jati. Setiap kapal memiliki 5 buah palka, yaitu 3 palka ikan dan 2 palka perlengkapan dengan daya tampung sekitar 30 ton. Nelayan di PPN Kejawanan Cirebon menggunakan jaring liongbun (bottom gillnet) untuk menangkap ikan Cucut. Menurut Fauziyah (1997), jaring liongbun sering disebut dengan jaring cucut, bottom gillnet, set bottom gillnet atau jaring insang tetap. Setiap kapal yang menggunakan bottom gillnet rata-rata beroperasi selama 60 - 90 hari. Sesuai dengan namanya, jaring ini dioperasikan dengan cara direntangkan dekat dasar perairan dengan bantuan jangkar. Jaring yang digunakan sebanyak 100 piece/ kapal dengan rata-rata ukuran mata jaring $50 \mathrm{~cm}$.

Langkah awal dalam pengoperasian penangkapan ikan Cucut ini sangat menentukan hasil tangkapan yang akan diperoleh, karena untuk menentukan lokasi penangkapan (fishing ground) ikan Cucut ini cukup sulit. Lokasi penangkapan ditentukan oleh nakhoda yang hanya menggunakan insting dan pengalaman dalam penangkapan yang dilakukan sebelum-sebelumnya. Pengoperasian alat tangkap bottom gillnet dilakukan mulai sore hari hingga pagi hari dengan posisi jaring yang menghadang arus. Hal ini di dukung oleh pendapat Yunanda (1998) dalam Irawan (2002) yang menjelaskan posisi jaring yang menghadang arus menyebabkan mata jaring terbuka sempurna, sehingga ikan yang menabrak jaring akan tertangkap secara terjerat (gilled) atau terbelit (engtangled).

\section{Sebaran Tangkapan Cucut berdasarkan Variasi Kedalaman di Laut Jawa}

Wilayah penangkapan ikan Cucut pada musim timur dan musim barat hampir sama karena berdasarkan hasil wawancara dengan beberapa nelayan, mereka melakukan penangkapan pada lokasi yang sudah pernah dilakukan penangkapan sebelumnya lalu berhasil mendapatkan ikan Cucut tanpa memperhatikan kondisi kedalaman yang sesuai untuk keberadaan ikan Cucut, karena mereka melakukan penangkapan setiap musim sepanjang tahun tergantung cuaca di perairan laut Jawa pada saat akan berangkat melaut. Daerah penangkapan ikan Cucut nelayan Cirebon yang menggunakan alat tangkap bottom gillnet adalah di sekitar laut Jawa, perairan Kalimantan Barat, Kalimantan Tengah, Kalimantan Selatan, dan Sumatera Selatan. Laut Jawa termasuk dalam laut dangkal, karena kedalamannya tidak lebih dari $200 \mathrm{~m}$ dengan substrat dasar lumpur.

Setiap jenis ikan Cucut menyukai habitat pada kedalaman yang berbeda-beda. Kedalaman laut Jawa yang termasuk dalam laut dangkal menjadi habitat yang sesuai bagi beberapa jenis ikan Cucut, namun laut Jawa memiliki kondisi oseanografi sangat dipengaruhi oleh cuaca (musim timur dan musim barat), sehingga mempengaruhi kegiatan penangkapan. Hal ini sesuai dengan pendapat Wyrtki (1961) yang mengemukakan bahwa kondisi oseanografi di laut Jawa dipengaruhi oleh adanya 2 angin muson, yaitu angin muson timur dan angin muson barat yang bertiup secara berkala sepanjang tahun di atas perairan laut Jawa.

Spesies ikan Cucut yang ditangkap di laut Jawa, didominasi oleh 2 jenis spesies ikan Cucut yaitu Cucut Depo (Rhinobatos schlegelii) dan Cucut Junjunan (Rhynchobatus djiddensis). Berdasarkan hasil yang didapat pada musim timur tahun 2011 kedua spesies ikan Cucut ini tersebar pada kedalaman $20-167 \mathrm{~m}$, dan pada musim timur 2012 didapatkan sebaran kedalaman antara 11 - 149 m. Penangkapan ikan Cucut Depo pada musim timur 2011 dan 2012 dilakukan sebanyak 28 kali, dengan hasil tangkapan tertinggi pada kedalaman $167 \mathrm{~m}$ di musim timur 2011 karena semakin dalam perairan maka hasil tangkapan cucut Depo cenderung meningkat, selain itu musim timur merupakan musim puncak penangkapan dari cucut Depo.

Sebaran cucut musim barat 2011 tersebar pada kedalaman 14 - 134 m dan pada musim barat 2012 tersebar pada kedalaman 14 - 120 m. Penangkapan ikan Cucut Depo yang dilakukan pada musim barat 2011 sebanyak 23 kali, dengan hasil tertinggi pada kedalaman 47 m dan pada musim barat 2012 sebanyak 17 kali dengan hasil tangkapan tertinggi pada kedalaman $20 \mathrm{~m}$, jumlah penangkapan yang dilakukan pada musim barat mengalami penurunan karena cuaca yang sering terjadi hujan sehingga menyebabkan terhambatnya kegiatan penangkapan, serta musim barat bukan merupakan musim puncak tangkapan cucut Depo.

Sebaran penangkapan ikan cucut Junjunan pada musim barat 2011 dilakukan penangkapan sebanyak 30 kali dengan hasil tangkapan tertinggi pada kedalaman $55 \mathrm{~m}$, namun pada kedalaman $14 \mathrm{~m}$ juga didapatkan hasil tangkapan cucut yang cukup tinggi dikarenakan musim barat merupakan musim puncak tangkapan cucut Junjunan sehingga pada setiap kedalaman, cucut Junjunan dapat tertangkap. Selain faktor kedalaman yang diduga mempengaruhi habitat Cucut yaitu substrat, karena ikan Cucut merupakan ikan demersal yang hidup di dasar perairan. Menurut Hartoko dan Pramono (2011), terdapat hubungan secara ekologi antara jenis substrat dasar laut dan kedalaman. Hal ini dapat mempengaruhi sebaran biota yang hidup di lingkungan tersebut, sehingga akan membentuk suatu 'ecological-cluster' atau pengkelasan ekologi. 


\section{Analisis Korelasi antara Kedalaman terhadap Hasil Tangkapan Cucut}

Secara umum berdasarkan hasil analisis korelasi dapat disimpulkan bahwa hubungan antara kedalaman terhadap hasil tangkapan Cucut rendah, karena disepanjang perairan laut Jawa memiliki kedalaman yang hampir merata dan merupakan laut dangkal, sehingga kedalaman hanya sedikit berpengaruh terhadap hasil tangkapan Cucut. Belum banyak penelitian yang dilakukan mengenai Cucut dengan ordo Rajiformes secara khusus, sehingga masih dibutuhkan informasi lebih lanjut mengenai Cucut jenis ini. Menurut Compagno dan Ishihara (2009), pengetahuan tentang habitat Cucut tidak diketahui secara pasti, tetapi perairan pantai merupakan daerah yang penting sebagai nursery ground, namun habitat cucut juga terkait dengan dampak kegiatan penangkapan ikan dan degradasi lingkungan/ polusi.

\section{Kesimpulan}

Kesimpulan yang dapat diambil dari penelitian Analisa Sebaran Spasial Ikan Cucut (Ordo Rajiformes) Berdasarkan Variasi Kedalaman di Perairan Laut Jawa adalah sebaran kedalaman di Laut Jawa yang menunjukkan daerah penangkapan ikan Cucut pada musim timur berkisar antara $11-167 \mathrm{~m}$, dengan kedalaman rata-rata $80 \mathrm{~m}$ untuk daerah penangkapan cucut Depo. Kedalaman pada musim barat berkisar antara $14-134 \mathrm{~m}$, dengan kedalaman rata-rata $50 \mathrm{~m}$ pada daerah penangkapan cucut Junjunan. Hal tersebut menunjukkan terjadi pengurangan kedalaman di setiap musimnya. Berdasarkan analisa korelasi antara sebaran kedalaman dengan hasil tangkapan Cucut pada musim timur dan musim barat di tahun $2011-2012$ mendapatkan nilai koefisien korelasi (r) dengan kisaran 0,184 - 0,329. Hal ini menunjukkan bahwa hubungannya rendah (tidak erat) yang berarti terdapat sedikit pengaruh sebaran kedalaman terhadap rata-rata hasil tangkapan cucut di laut Jawa.

\section{Ucapan Terima Kasih}

Penulis mengucapkan terimakasih kepada Prof. Dr. Ir. Sahala Hutabarat, M.Sc dan Prof. Dr. Ir. Agus Hartoko, M.Sc atas bimbingan dan arahannya dalam penyusunan jurnal ini.

\section{Daftar Pustaka}

Bres, M. 1993. The behaviour of sharks. Reviews in Fish Biology and Fisheries 3:133-159.

Compagno, L.J.V. and H. Ishihara. 2009. Rhinobatos schlegelii. In: IUCN 2013. IUCN Red List of Threatened Species. Version 2013.1. www.iucnredlist.org (Diakses tanggal 5 Agustus 2013).

Direktorat Jenderal Perikanan Tangkap. 2012. Laporan Akuntabilitas Kinerja Instansi Pemerintah (LAKIP) Direktorat Jenderal Perikanan Tangkap Tahun 2012. Kementerian Kelautan dan Perikanan. Jakarta.

FAO (Food and Agriculture Organization). 2002. FAO Species catalogue for Fishery purpose. Sharks of the world an annotated and illustrated catalogue of sharks species known to date. Vol.2. Bullhead, mackerel and carpet sharks (Heterodontiformes, Lamniformes and Orectolobiformes).FAO. Rome. 269 pp.

Fauziyah. 1997. Studi tentang Efisiensi Teknis Unit Penangkapan Jaring Cucut (Liong Bun) di Cirebon. [Skripsi]. Program Studi Pemanfaatan Sumberdaya Perikanan. Fakultas Perikanan dan Ilmu Kelautan. Institut Pertanian Bogor. Bogor. 58 hal.

Hadi, S. 2004. Metodologi Research. Andi, Yogyakarta, 300 - $303 \mathrm{hlm}$.

Hamidi. 2007. Metode Penelitian dan Teori Komunikasi. Press Malang, Malang.

Hartoko, A dan M. Helmi. 2004. Development of Multilayer Ecosystem Parameters Model. J. Coast. Dev. 7(3): 129-136.

Hartoko, A dan W. Pramono. 2011. Multi Layer Spatial Analysis For Demersal Shrimp Fishery And Sst Warming In The Semarang Coastal Waters. J. Coast. Dev. 15(1): 17-23.

Hutabarat, S. dan S. M. Evans. 1985. Pengantar Oseanografi. Universitas Indonesia Press. Jakarta. 159 hal.

Irawan, D. 2002. Produktivitas Jaring Liongbun (Gillnet Cucut) Terhadap Ikan Depo dan Ikan Junjunan di Perairan Utara Pulau Jawa. [Skripsi]. FPIK. IPB. 59 hal.

Lillesand T.M., and R.W. Kiefer. 1987. Remote Sensing and Image Interpretation. Second Edition. Canada.

Nasir, M. 1983. Metode Penelitian. Ghalia Indonesia, Jakarta, $234 \mathrm{hlm}$.

Pyers, G. 2000. Sharks. Periplus, Singapore. 63 pp.

Susanti, A. 1997. Studi Tentang Jenis dan Penyebaran Hiu yang Potensial Dimanfaatkan di Perairan Indonesia. [Skripsi]. Program Studi Pemanfaatan Sumberdaya Perikanan. Fakultas Perikanan dan Ilmu kelautan. Institut Pertanian Bogor. 84 hal.

Thurman, H. V. 1997. Introductory Oceanography. New Jersey, USA: Prentice Hall College, ISBN 0132620723

Wyrtki, K. 1961. Physical Oceanography of South East Asian Waters. Naga Report, Vol. 2. The University of California Scripps Institution of Oceanography. La Jolla. California. 